\section{UTICAJ DODATKA ELEKTROFILTERSKOG LETEĆEG PEPELA NA ZATEZNE ČVRSTOĆE CEMENTNIH STABILIZACIJA OD ŠLJUNKA}

Milija Stojanović, dipl.građ.inž.

Univerzitet u Novom Sadu, Fakultet tehničkih nauka, Departman za građevinarstvo i geodeziju, milijastojanovic@gmail.com

Prof.dr Vlastimir Radonjanin, dipl.građ.inž.

Univerzitet u Novom Sadu, Fakultet tehničkih nauka, Departman za građevinarstvo i geodeziju, radonv@uns.ac.rs

Prof.dr Mirjana Malešev, dipl.građ.inž.

Univerzitet u Novom Sadu, Fakultet tehničkih nauka, Departman za građevinarstvo i geodeziju, miram@uns.ac.rs

dr Bojan Matić, dipl.građ.inž.

Univerzitet u Novom Sadu, Fakultet tehničkih nauka, Departman za građevinarstvo i geodeziju, bojanm@uns.ac.rs

Saeeda Furgan, dipl.građ.inž.

Univerzitet u Novom Sadu, Fakultet tehničkih nauka, Departman za građevinarstvo i geodeziju

\section{DOI: $10.31075 /$ PIS.64.02.05}

Stručni rad

Rezime: $U$ radu je analiziran uticaj količine $i$ vrste veziva (portland cementa i elektrofilterskog letećeg pepela iz termoelektrana) na vrednost indirektne zatezne čvrstoće (ITS) cementnih stabilizacija kolovoznih konstrukcija. Agregat koji je stabilizovan navedenim vezivnim materijalima bio je trofrakcijski rečni šljunak. $U$ eksperimentalnom istraživanju varirana je ukupna količina veziva, kao $i$ procentualno učešće portland cementa i elektrofilterskog letećeg pepela. Opisane su osnovne karakteristike stabilizacijskih mješavina sa navedenim komponentnim materijalima. Laboratorijska ispitivanja su podeljena $u$ dve faze. $U$ prvoj fazi su Proctor-ovim opitom određene suve zapreminske mase mešavina za različite količine vode $i$ ispitana njihova zavisnost $u$ odnosu na ukupnu količinu veziva $i$ procentualno učešće elektrofilterskog letećeg pepela. Druga faza je obuhvatila spravljanje uzoraka $i$ ispitivanje indirektnie zatezne čvrstoće, koja je obavezan uslov kvaliteta cementne stabilizacije. Indirektna zatezna čvrstoća je određena za dva različita perioda nege uzoraka. Osnovni cilj rada je bio da se kroz teorijsko $i$ eksperimentalno istraživanje provere mogućnosti primene otpadnog materijala, kao što je elektrofilterski leteći pepeo, u izradi kolovoznih konstrukcija, sa osvrtom na zatezne čvrstoće stabilizacije.

Ključne reči: cementna stabilizacija, elektrofilterski leteći pepeo, indirektna zatezna čvrstoća (ITS), životna sredina.

\section{THE IMPACT OF THE ELECTROPHYTICAL SUPPLY SUMMER PIPELINE ON TENSIONAL STRENGTHS OF CEMENT STABILIZATION OF PULSE}

\section{Milija Stojanović, M.Sc. C.E.}

University of Novi Sad, Faculty of Technical Sciences, Department of Civil Engineering and Geodesy, milijastojanovic@gmail.com

Vlastimir Radonjanin, Ph.D., C.E.

University of Novi Sad, Faculty of Technical Sciences, Department of Civil Engineering and Geodesy, radonv@uns.ac.rs

Mirjana Malešev, Ph.D., C.E.

University of Novi Sad, Faculty of Technical Sciences, Department of Civil Engineering and Geodesy, miram@uns.ac.rs

Bojan Matić, Ph.D., C.E.

University of Novi Sad, Faculty of Technical Sciences, Department of Civil Engineering and Geodesy, bojanm@uns.ac.rs

\section{Saeeda Furgan, M.Sc. C.E.}

University of Novi Sad, Faculty of Technical Sciences, Department of Civil Engineering and Geodesy

Professional paper Summary: The paper analyzes the influence of the quantity and type of binder (portland cement and flywheel fly ash from thermal power plants) on the value of indirect tensile strength (ITS) of cement stabilization of pavement structures. The aggregate stabilized by the said binder materials was a trofractic river pebbles. In the experimental study, the total amount of binders varies, as well as the percentage participation of portland cement and fly ash fly ash. The basic characteristics of stabilization mixtures with specified components are described. Laboratory tests are divided into two phases. In the first phase, Proctor's experiment determined certain dry masses of mixtures for different quantities of water and tested their dependence on the total amount of binder and the percentage participation of electro-flyer fly ash. The second phase included sampling and testing of indirect tensile strength, which is an obligatory condition for the quality of cement stabilization. Indirect tensile strength is determined for two different periods of sample care. The main goal of the work was to verify, through theoretical and experimental research, the possibility of applying waste material, such as electrophilter fly ash, in the construction of pavement structures, with a reference to the tensile strength of the stabilization.

Key words: cement stabilization, fly ash fly ash, indirect tensile strength (ITS), environment.

\section{UVOD}

Dimenzionisanje slojeva kolovozne konstrukcije i njihov sastav zavise od više faktora, a osnovni parametar koji ih određuje je vrednost saobraćajnog opterećnja za koju se kolovozna konstrukcija projektuje. 
Veće saobraćajno opterećenje zahteva ugradnju kvalitetnijih nosećih slojeva kolovozne konstrukcije čija funkcija je prijem i prenos opterećenje na posteljicu. Jedan od tih nosećih slojeva je i sloj cementne stabilizacije. Tradicionalna izrada stabilizacija kolovoznih konstrukcija, sa prirodnim agregatima i cementnim vezivima, u poslednje vreme se u svetu sve manje koristi, a prednosti se daju novijim tipovima gradnje. Brojna istraživanjima dokazuju da je izrada stabilizacija kolovoznih konstrukcija moguća i opravdana i uz upotrebu nekih drugih materijala, pri čemu se akcenat stavlja na primenu industrijskih nusproizvoda. Tako se $u$ zamenu za cement, kao vezivo mogu koristiti: elektrofilterski leteći pepeo i šljaka iz termoelektrana, granulisana zgura iz visokih industrijskih peći i razne vrste biopepela. Njihova pucolanska svojstva su već dokazana, a navedeni materijali se dugi niz godina uspešno primjenjuju kao zamena za deo cementa $u$ klasičnim betonskim konstrukcijama.

Primena otpadnih materijala, u svojstvu veziva $u$ stabilizacijama kolovoznih konstrukcija, je jedan od načina smanjenja deponija tih materijala, koje predstavljaju veliki problem u mnogim državama sveta, pa i u Srbiji. Gradnja novih i/ili rekonstrukcija postojećih kolovoznih konstrukcija uspešno se izvodi i uz primenu nekih otpadnih materijala, u koje se može svrstati i industrujski nusproizvod iz termoelektrana - elektrofilterski leteći pepeo. Veća primena elektrofilterskog letećeg pepela u gradnji puteva ima veliku opravdanost i ostvarivanje brojnih ušteda. Te uštede se ogledaju u: ekonomskim, ekološkim, materijalnim, energetskim, vremenskim, sigurnosnim i mnogim drugim aspektima.

\section{ELEKTROFILTERSKI LETEĆI PEPEO}

Elektrofilterski leteći pepeo $(F A \text { - Fly Ash })^{1}$ predstavlja fini mineralni ostatak spaljivanja mlevenog uglja u pećima termoelektrana, pri čemu zajedno sa izduvnim gasovima izlazi iz kotla. Tokom procesa nastanka električne energije, ugalj $u$ termoelektranama sagoreva pri temperaturama od 1000 do $1600^{\circ} \mathrm{C}$. U tom procesu organski sastojci izgore, a mineralne nečistoće iz uglja (kao što su kvarc i glina) ostaju kao neizgoreli. Taj ostatak se brzo transportuje u zonu sa nižim temepraturama (gde se solidifikuje), u obliku sfernih staklastih čestica, te se dobije fini prah koji se, zajedno sa gasovima iz dimnjaka mehaničkim i elektrostatičkim putem (u elektrostatičkim filterima) sakuplja $u$ posebne silose za pepeo [1]. Takav pepeo je poznat kao usitnjeni pepeo i čini oko 75-85\% ukupne količine pepela. Ostatak predstavljaju krupnije čestice pepela koje padaju na dno peći, gde se formira tzv. pepeo sa dna peći.
Na XIII Svetskom kongresu za puteve, koji je održan 1983.godine u Sidneju (Australija), leteći pepeo iz termoelektrana je klasifikovan kao industrijski nusproizvod, koji nastaje u postrojenjima za proizvodnju električne energije [2]. U Republici Srbiji je leteći pepeo definisan kao najvažniji neorganski, sekundarni materijal [2], a prema autoru P.Braunoviću [3] leteći pepeo se može svrstati u grupu veštačkih pucolanskih materijala.

\subsection{Hemijski sastav i fizičke karakteristike}

Hemijska svojstva letećeg pepela su najbitniji indikator kod ocene njegove podobnosti primene $\mathrm{u}$ svojstvu građevinskog materijala, ili kao sirovine za njegovu proizvodnju. Mnoga laboratoriska ispitivanja su pokazala da presudni uticaj na fizičko-hemijska svojstva letećeg pepela imaju vrsta i kvalitet uglja, kao i stepen njegove usitnjenosti. Laboratorijskim ispitivanjima je utvrđeno da se leteći pepeo nastao od lignitskog i mrkog uglja znatno razlikuje, po svom sastavu i kvalitetu, od pepela koji je dobijen sagorevanjem kamenog uglja. Istraživanja su pokazala da se leteći pepeo uglavnom sastoji od preko $85 \%$ aluminata, silikata, oksida gvožđa i magnezijuma, u širokim rasponima varijacija pojedinih komponenata [4].

Boja letećeg pepela je nepouzdan indikator njegovog hemijskog sastava, a uglavnom varira od svetlog tona, preko nijansi sive do crne. Pepeo koji se dobija od lignita ili delimično bitumeniziranog uglja obično ima svetlu ili bledu mrkožutu boju. Svetlije nijanse sive boje ukazuju na bolji kvalitet pepela. Bakarna boja je obično povezana sa prisustvom fero-oksida, dok tamnije boje ukazuju na prosustvo ugljenika [5].

Specifična masa letećeg pepela varira u zavisnosti od njegovog porekla, a najčešće je u rasponu od oko 1700 do $3000 \mathrm{~kg} / \mathrm{m}^{3}$. Najzastupljenije vrednosti specifične mase su između 2000 i $2800 \mathrm{~kg} / \mathrm{m}^{3}$ [6].

\subsection{Pucolanska svojstva letećeg pepela}

Još od ranije je poznato da leteći pepeo ima pucolanske karakteristike i kao takav pronalazi svoju bitnu primenu u betonskim mešavinama. Leteći pepeo je se svrstava u grupu industrijskih pucolana i smatra se za najčešće upotrebljavani pucolan, a poznat je i pod nazivom moderni pucolan [7].

Hidratacija letećeg pepela je proces očvršćavanja cementnog kamena usled reakcije kreča i pucolana $\left(\mathrm{SiO}_{2}, \mathrm{Al}_{2} \mathrm{O}_{3}, \mathrm{Fe}_{2} \mathrm{O}_{3}\right)$ uz prisustvo vode.

Pucolanska reakcija koja se odvija tom prilikom u cementnim stabilizacijama je sledeća [7]:

\footnotetext{
${ }^{1} \mathrm{U}$ nastavku rada koristiće se termin leteći pepeo
} 


$$
\begin{array}{lll}
\mathrm{CaO}+\mathrm{H}_{2} \mathrm{O} & \Rightarrow & \mathrm{Ca}(\mathrm{OH})_{2} \\
\mathrm{Ca}(\mathrm{OH})_{2} & \Rightarrow & \mathrm{Ca}^{++}+2[\mathrm{OH}]^{-} \\
\mathrm{Ca}^{++}+2[\mathrm{OH}]^{-}+\mathrm{SiO}_{2} & \Rightarrow & \mathrm{CSH} \text { (gel) } \\
\mathrm{Ca}^{++}+2[\mathrm{OH}]^{-}+\mathrm{Al}_{2} \mathrm{O}_{3} & \Rightarrow & \mathrm{CAH} \text { (gel) }
\end{array}
$$

Leteći pepeo je samostalno slabo ili nimalo hidraulično aktivno vezivo, međutim u praškastom stanju i u kontaktu sa vodom, reaguje hemijski sa kalcijum hidroksidom $\left(\mathrm{Ca}(\mathrm{OH})_{2}\right)$ i kalcijum oksidom $(\mathrm{CaO})$ i pri sobnoj temperaturi formira jedinjenja koja imaju vezivna svojstva [3].

\subsection{Primena letećeg pepela kroz istoriju mogućnosti upotrebe u građevinarstvu}

Termin leteći pepeo prvi put se službeno pominje $u$ literaturi 1937.godine u SAD-u, kada su objavljeni rezultati naučnog istraživanja američkog instituta za beton - $\mathrm{ACl}$ (American Concrete Institute). Njegova značajnija primena, kao dodatka cementu, prvi put je zabeležena prilikom izgradnje brane Hungry Horse Dam 1948.godine, kada je u branu ugrađeno 120.000 tona letećeg pepela. Nakon toga, u SAD je leteći pepeo počeo da se primenjuje i u gradnji puteva i to u mešavinama za izradu nosećih slojeva kolovoznih konstrukcija pod nazivom Poz-o-Pac, što u stvari predstavlja početak njegove primene u cemenetnim stabilizacijama. Ovaj proizvod sadržao je mešavinu agregata (drobljenog kamena i šljunka lokalnog karaktera), kreča i letećeg pepela [7]. Primena letećeg pepela u građevinskoj industriji (pored razlike $u$ ceni $u$ odnosu na cement) se razvijala i usled problema sa njegovim deponovanjem. U Kini su prva istraživanja letećeg pepela, kao građevinskog matrerijala, počela 1950.godine. Danas su cementare, fabrike građevinskih materijala i firme za gradnju puteva najveći potrošači letećeg pepela u Kini, zemlji koja se smatra najvećim proizvođačem letećeg pepela u svetu [8].

Bitan razlog povećane primene letećeg pepela, je činjenica da ima pucolanska svojstva i mogućnost povećanja čvrstoća kroz vreme i do par godina nakon njegove ugradnje, pa betonske mešavine sa letećim pepelom mogu da dostignu čvrstoće koje su karakteristične za klasične betonske konstrukcije. Vrednosti ranih čvrstoća mešavina sa dodatkom letećeg pepela su uglavnom niske, a njihov prirast je sporiji od mešavina sa dodatkom samo cementa [7]. Činjenica da ovakvi kompozitni materijali imaju niske rane čvrstoće, nekada može predstavljati ograničavajući faktor u upotrebi letećeg pepela i tu činjenicu treba uzeti u obzir tokom prokjektovanja kolovoznih kontrukcija. Sa povećanjem učešća letećeg pepela $u$ betonskim mešavinama rane pritisne čvrstoće se uglavnom smanjuju, a kasnije povećavaju (grafikon 1.) [1].
Isto zapažanje se uočava i kod analize čvrstoća na savijanje betonskih mešavina sa dodatkom letećeg pepela (grafikon 2.).

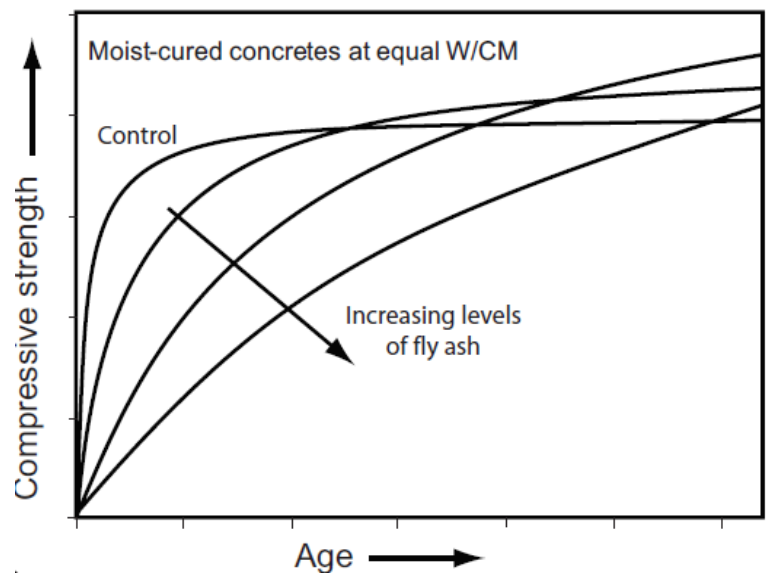

Grafikon 1. Uticaj dodatka letećeg pepela na razvoj pritisnih čvrstoća betonskih konstrukcija u toku vremena Izvor: (Thomas, M. [1])

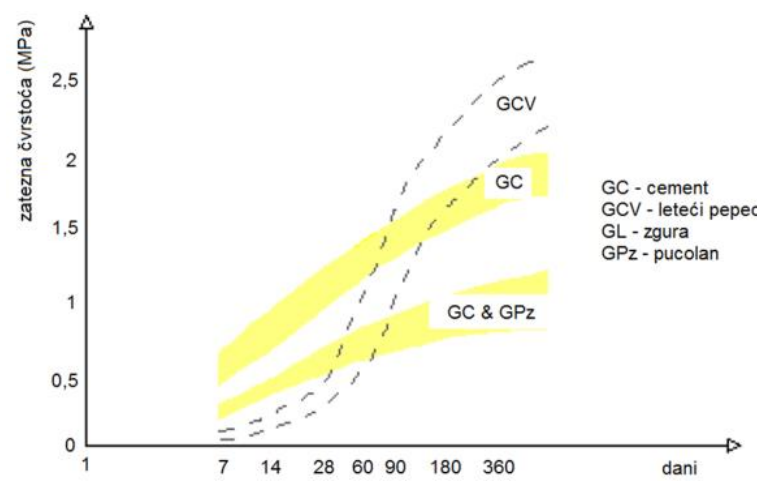

Grafikon 2. Razvoj čvrstoća na savijanje i njihove vrednosti za stabilizacije sa različitim vrstama veziva Izvor: (Dimter, S., Šperac, M. [7])

Na osnovu grafikona 1. i 2. može se zaključiti i da su čvrstoće na pritisak i savijanje kod konstrukcija sa većim učešćem letećeg pepela, nakon 90 i više dana nege, približno iste ili veće $u$ odnosu na kontrolne, čisto betonske (cementne) konstrukcije.

Leteći pepeo, kao industrijski nusproizvod, već dugi niz godina predstavlja ozbiljan problem, kako zbog njegove količine tako i zbog njegovog štetnog uticaja na životnu sredinu.

Brojne su mogućnosti upotrebe letećeg pepela $u$ građevinarstvu, samostalno ili u kombinaciji sa drugim materijalima, a neke od njih su:

1) za poboljšanje fizičkih i mehaničkih karakteristika očvrslog betona;

2) kao deo zamene za cement u betonskim mešavinama;

3) u proizvodnji cementa; 
4) u proizvodnji lakih agregata, betona i betonskih prefabrikata;

5) za isušivanje podtla građevinskih objekata;

6) za stabilizaciju slabo nosivog tla, samostalno ili u kombinaciji sa drugim vezivnim sredstvima;

7) za stabilizaciju donjih i gornjih nosećih slojeva kolovoznih konstrukcija;

8) za stabilizaciju nasipa;

9) u izradi asfaltnih mešavina;

10) kod sanacije oštećenih površina kolovoza i sanacije klizišta;

11) za injektiranje, tj. pravljenje injekcionih smesa;

12) za stabilizaciju otpada i njegovo očvršćavanje (ukrućivanje) i drugo.

\subsection{Proizvodnja letećeg pepela i dosadašnja primena u Srbiji i svetu}

Prema statističkim podacima u Republici Srbiji se u termoelektranama za proizvodnju električne energije godišnje troši oko 35 miliona tona uglja, uglavnom lignitskog porekla. Pored proizvedene električne energije godišnje se proizvede i oko 7 miliona tona otpadnog letećeg pepela i šljake, kao nusproizvoda [2]. Proizvodnja letećeg pepela i šljake u proseku iznosi oko $20 \%$ od količine upotrebljenog uglja. Navedeni podaci svrstavaju leteći pepeo i šljaku u najzastupnjeniji sekundarni otpad u Srbiji, a Srbiju u red svetskih zemalja sa najvećom proizvodnjom letećeg pepela (u odnosu na broj stanovnika) [8].

Problem velikih količina proizvedenog i deponovanog otpadnog letećeg pepela u svetu nije nov, već je star onoliko koliko je stara proizvodnja električne energije u termoelektranama. Autor P.Braunović [3] navodi da su se još 1980.godine u svetu javljali problemi sa velikim količinama letećeg pepela, čija proizvodnja je u tom periodu, u SAD iznosila oko 40 miliona tona godišnje.

Upotreba letećeg pepela u Srbiji je u svim privrednim granama, pa i u gradnji puteva, veoma mala. Postoje samo pojedinačni primeri deonica na kojima je rađena kolovozna konstrukcija sa dodatkom pepela. Za razliku od Srbije, veći dio Evrope, ima nešto manje problema sa letećim pepelom i njegovim deponijama, jer je njegova primena u industiji evropskih zemalja značajno veća. U 15 zemalja Evropske Unije proizvodnja letećeg pepela za 2010.godinu iznosila je oko 14 miliona tona, a od te količine najveći deo se koristio za proizvodnju betona (oko 35\%) i za gradnju puteva (oko 25\%) [9].

Razlika u količini proizvedenog i upotrebljenog letećeg pepela u svetu varira iz godine u godinu, ali poslednjih godina ima tendenciju postepenog smanjenja. Iskorišćenost letećeg pepela (za 2010.godinu) bila je najveća u nekim evropskim zemljama (Danskoj, Holandija i Italiji) i Australiji, dok je za najveće svetske proizvođače (Indiju i Kinu) ta iskorišćenost bila ispod 50\% [10] (dijagram 1.).

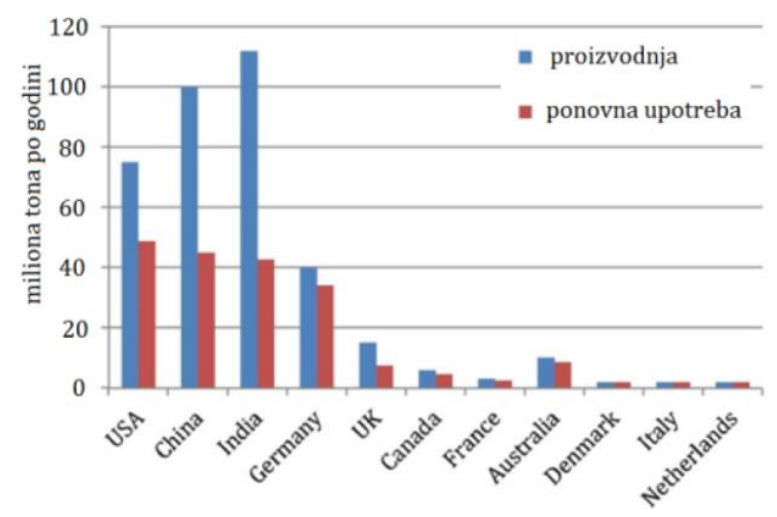

Dijagram 1. Odnos proizvodnje i primene letećeg pepela za pojedine svetske zemlje (za 2010.god.)

Izvor: (Mahvash, S., López-Quero, S., Bahadori-Jahromi, A. [10])

\subsection{Primena letećeg pepela kod stabilizacija nosećih slojeva kolovoznih konstrukcija}

Izrada cementnih stabilizacija sa dodatkom letećeg pepela smatra se jednim od prvih slučajeva primene otpadnih materijala u gradnji nosećih slojeva kolovoznih konstrukcija. Stablizacije sa cementom ili krečom, u kombinaciji sa nekim otpadnim materijalima (kao što je leteći pepeo), neki autori nazivaju kompleksno stabilizovane mešavine (KSM) [3].

Zbog pucolanskih svojstava i svojstva samovezivanja, leteći pepeo se može uspešno koristiti kao vezivo ili dopuna vezivu i u izradi stabilizovanih gornjih i donjih nosećih slojeva kolovoznih konstrukcija, bilo da se radi o sitnozrnom ili krupnozrnom agregatu. Laboratorijska i terenska ispitivanja su pokazala da se leteći pepeo može uključiti u proračun nosivost polukrutih kolovoznih konstrukcija. Ukoliko se u stabilizacijskim mešavinama koristi pepeo klase $F$ (klasifikacija po: ASTM C618) mešavini je potrebno dodati i aktivator, kako bi se podstakla pucolanska reakcija. Najčešće korišćeni aktivatori su kreč i cement, mada se koriste i cementna i krečnjačka prašina iz peći za žarenje, kao i kombinacija navedenih materijala. Samovezujući pepeo klase $C$ (klasifikacija po: $A S T M$ C618) ne zahteva aktivator i kao takav nudi ekonomičnije alternative za širok spektar primena u cementnim stabilizacijama. Zadovoljavajuće karakteristike stabilizacijskih mešavina zavise od prirasta čvrstoće unutar mase, koja nastaje pucolanskom reakcijom između letećeg pepela i aktivatora. Ova vezivna masa ima ulogu da drži zajedno zrna agregata, slično kao kod betona niskih čvrstoća.

$U$ početku, primena letećeg pepela u cementnim stabilizacijama se odnosila samo za lokalne saobraćajnice nižeg ranga i sa lakim saobraćajnim opterećenjem. Vremenom se pepeo počeo koristiti i za stabilizacije sa većim saobraćajnim opterećenjem, pa i na auto-putevima. 
Primena letećeg pepela se može odnositi, kako za izradu novih saobraćajnica, tako i za rekonstrukciju postojećih oštećenih kolovoznih konstrukcija. Takođe, leteći pepeo, kao vezivo, uspešno se može primeniti prilikom rekonstrukcije puteva postupkom reciklaže asfaltnih slojeva, za sve njene tipove [11].

\subsection{Cilj primene stabilizacija sa dodatkom letećeg pepela}

Krajnji cilj primene letećeg pepela u izradi cementnih stabilizacija kolovoznih konstrukcija je:

1) Povećanje primene otpadnih materijala;

2) Smanjenje potrebne količine cementa pri izradi stabilizacija;

3) Poboljšanje kvaliteta kolovozne konstrukcije i uslova odvijanja saobraćaja;

4) Ostvarivanje ekonomskih ušteda upotrebom otpadnih i jeftinih materijala;

5) Upravljanje otpadom i smanjenje deponija letećeg pepela;

6) Ispunjenje ekoloških zahteva i promocija održive gradnje.

\subsection{Prednosti upotrebe letećeg pepela u izrad cementnih stabilizacija}

Cementne stabilizacije sa dodatkom letećeg pepela imaju brojne prednosti primene, a neke od njih su:

1) Povećanje mehaničkih karakteristika $u$ toku vremena (zbog kasnije pucolanske reakcije);

2) Veća trajnost stabilizacije;

3) Veća obradivost sveže betonske mešavine;

4) Povećanje nosivosti polukrute kolovozne konstrukcije;

5) Rast zateznih čvrstoća očvrsle cementne stabilizacije;

6) Redukcija izdvajanja vode u mešavinama sa letećim pepelom;

7) Smanjenje/redukcija vodopropusnosti;

8) Veća otpornost na dejstvo sulfata;

9) Niža cena koštanja ukupne konstrukcije;

10) Smanjenje primene skupljih veziva (cementa i kreča);

11) Smanjenje poroznosti betona;

12) Mogućnost „zarastanja“ prslina i pukotina u toku eksploatacije puta;

13) Smanjenje skupljanja u betonu;

14) Smanjenje toplotne hidratacije cementa;

15) Smanjenje emisije $\mathrm{CO}_{2} \mathrm{u}$ atmosferu;

16) Smanjenje deponija letećeg pepela, a samim tim i štetnog uticaja na ekosistem.

\subsection{Leteći pepeo i životna sredina}

Kako u svetu tako i u Srbiji potrebe za električnom energijom stalno rastu, a samim tim i potrebe za većom eksploatacijom uglja, kao sirovine za njenu prozvodnju u termoelektranama. Uporedo sa tim, povećavaju se i deponije letećeg pepela, pa je zbog toga potrebno posvetiti veću pažnju rešavanju veoma složenog problema njegovog deponovanja. Da bi se smanjile deponije letećeg pepela i njegov štetni uticaj po čoveka i okolinu razvijene svetske zemlje konstantno otkrivaju nove mogućnosti primene ovog industrijskog nusproizvoda.

Cementna industrija je odgovorna za emisiju najmanje $5-7 \%$ ukupnog ugljendioksida $\left(\mathrm{CO}_{2}\right) \mathrm{u}$ atmosferu. Do emisije $\left(\mathrm{CO}_{2}\right)$ u cementarama dolazi u toku procesa dobijanja oksida kalcijuma iz krečnjaka (oko 60\%) i usled visokih temperatura, potrebnih za odvijanje ovih procesa (oko 40\%) [12]. Većom upotrebom letećeg pepela, kao zamene za cement u betonskim kompozitima, štetna emisija $\mathrm{CO}_{2}$ bi se značajno smanjila. Gasovi kao što su ugljendioksid i azotni oksidi, nastali usljed proizvodnje cementa ili sagorevanja uglja, utiču i na pojavu nastanka kiselih kiša i efekta staklene bašte.

Državna regulativa SAD-a, koja se odnosi na zaštitu životne sredine, regulisala je upravljanje deponijama letećeg pepela, zbog mogućnosti rastvaranja njegovih mikroelemenata $u$ atmosferskim vodama. Ako se leteći pepeo koristi u betonu, mogućnost izdvajanja mikroelemenata je veoma niska, jer su sastojci pepela zatvoreni u betonskoj masi. Izdvajanje mikroelemenata iz letećeg pepela je moguće kod njegove neizolovane upotrebe. Upotreba letećeg pepela $u$ nasipima ili stabilizovanim slojevima kolovozne konstrukcije zahteva pažljivu upotrebu, kako bi se negativni uticaji na životnu sredinu sveli na minimum.

\section{EKSPERIMNETALNO ISTRAŽIVANJE}

U sklopu eksperimentalnog istaživanja dati su rezultati ispitivanja Proctor-ovog opita i indirektnih zateznih čvrstoća (ITS) za 6 različitih stabilizacijskih mešavina, nakon 7 i 28 dana nege cilindričnih uzoraka. Cilindrični uzorci su spravljeni u metalnim kalupima, na osnovu prethodno definisanih optimalnih vlažnosti ( $\left.W_{\text {opt}}\right)$ za različite mešavine. Optimalne vlažnosti su definisane u postupku određivanja Proctor-ovog opita.

\subsection{Komponentni materijali}

Komponentni materijali (slike 1., 2., 3. i 4.) koji su korišćeni u eksperimentalnom istraživanju bili su:

- prirodni agregat - trofrakcijski šljunak (Dunavac, deponija Veternik);

- cement CEM II/B-M (V-L) 32,5R (fabrika Lafarge, Beočin);

- elektrofilterski leteći pepeo (iz termoelektrane Nikola Tesla B, Obrenovac). 


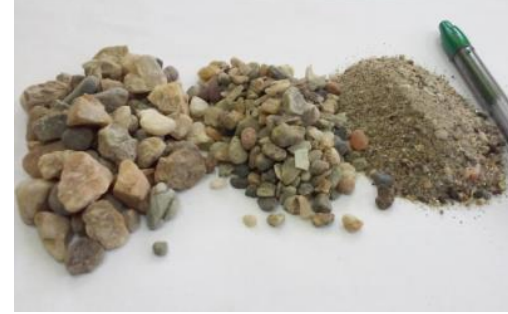

Slika 1. Prirodni agregat - šljunak ( $G$ - Gravel), frakcije $8 / 16,4 / 8,0 / 4$

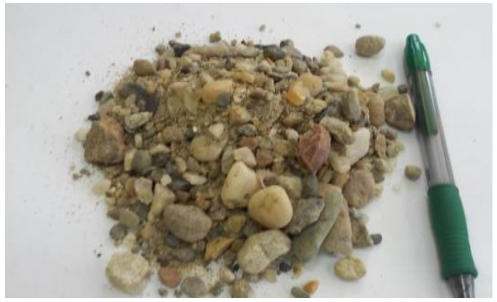

Slika 2. Prirodni agregat (šljunak),mešavina tri frakcije $(0 / 4,4 / 8$ i $8 / 16)$

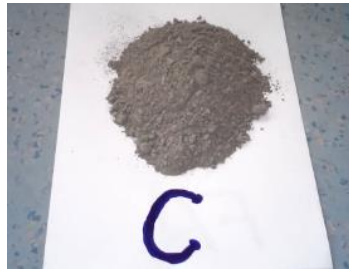

Slika 3. Cement $(C)$

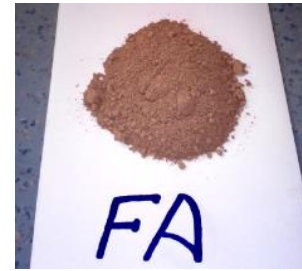

Slika 4. Leteći pepeo (FA - Fly Ash)
$\mathrm{Na}$ slici 1. su pojedinačno prikazane tri frakcije prirodnog agregata (šljunka) koje su korišćene u istraživanju, dok je na slici 2. prikazana njihova mešavina. Datoj mešavini agregata su u toku spravljanja uzoraka dodati vezivo (cement i leteći pepeo) i voda, u različitim procentualnim odnosima. Granulometrijski sastav mešavine prirodnog agegata (datog na slici 2.) određen je po standardnu SRPS U.B1.018:2005, a rezultati ispitivanja dati su na grafikonu 3. Analizom date granulometriske krive (grafikon 3.) može se zaključiti da postoji blagi diskontinuitet na delu krive koji prikazuje procentualno učešće veličine zrna agregata od $0,25 \mathrm{~mm}$ do $0,50 \mathrm{~mm}$, što je uglavnom karakteristika prirodnog šljunka datog porekla.

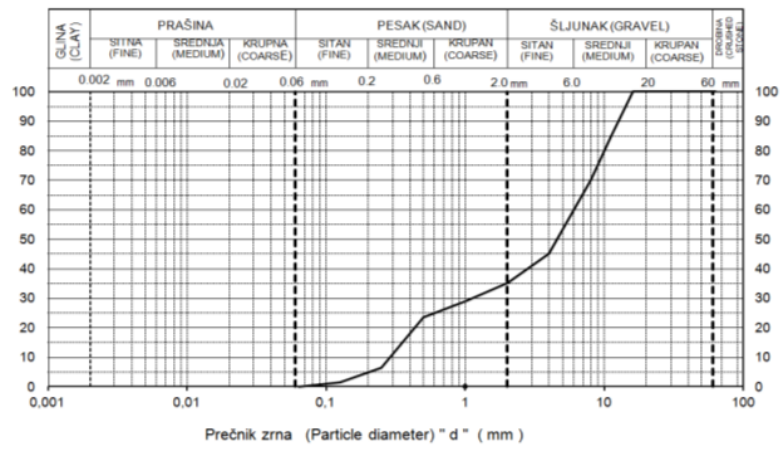

Grafikon 3. Granulometrijska kriva prirodnog agregata (šljunka) koji je korišćen u eksperimentalnom istraživanju
Učešće frakcije 1 (0/4) u ukupnoj mešavini je iznosilo 45\%mas (grafikon 3.). Uloga date frakcije u stabilizacijskim mešavinama je veoma bitna zbog ostvarivanja kompaktne mešavine tokom zbijanja, u postupku spravljanja uzoraka. Postupak zbijanja se obavljao Proctor-ovim nabijačem u metalnom cilindričnom kalupu sa nastavkom.

Pritisna čvrstoća portland kompozitnog cementa korišćenog $\mathrm{u}$ istraživanju (CEM II/B-M (V-L) 32,5R) nakon 2 dana nege iznosila je 16,20MPa, a nakon 28 dana nege 42,14MPa. Vrednosti savojne čvrstoće su bile $4,15 \mathrm{MPa}$ (nakon 2 dana nege) i $8,21 \mathrm{MPa}$ (nakon 28 dana nege). Ispitivanje navedenih čvrstoća rađeno je na osnovu standarda SRPS EN 196-1:2008.

Kao zamena za deo cementnog veziva, tokom eksperimentalnog istraživanja, u određenim procentualnim iznosima korišćen je leteći pepeo. Pre spravljanja stabilizacijskih uzoraka leteći pepeo je samleven i prosejan kroz sito $0,125 \mathrm{~mm}$. Hemijski sastav pepela koji je korišćen u ovom istraživanju prikazan je u tabeli 1.

Tabela 1. Hemijski sastav letećeg pepela

\begin{tabular}{|c|c|}
\hline Hemijski elemenat & Učešće [\%] \\
\hline $\mathrm{SiO}_{2}$ & 50,08 \\
\hline $\mathrm{Al}_{2} \mathrm{O}_{3}$ & 18,55 \\
\hline $\mathrm{Fe}_{2} \mathrm{O}_{3}$ & 5,84 \\
\hline $\mathrm{TiO}_{2}$ & 0,51 \\
\hline $\mathrm{CaO}$ & 11,29 \\
\hline $\mathrm{MgO}$ & 1,34 \\
\hline $\mathrm{Na}_{2} \mathrm{O}$ & 0,74 \\
\hline $\mathrm{K}_{2} \mathrm{O}$ & 1,79 \\
\hline $\mathrm{SO}_{3}$ & 2,63 \\
\hline $\mathrm{MnO}$ & 0,02 \\
\hline Gubitak žarenjem na $950^{\circ} \mathrm{C}$ & 7,16 \\
\hline
\end{tabular}

Analizom rezultata ispitivanja datih u tabeli 1. leteći pepeo korišćen u ovom istraživanju se na osnovu američkog standarda ASTM C618 može svrstati u pepeo klase $F$, dok se na osnovu standarda SRPS EN 197-1:2010 može klasifikovati kao krečnjački pepeo. Prosečna vrednost pritisnih čvrstoća letećeg pepela je iznosila 45,94MPa, a čvrstoća na zatezanje pri savijanju $8,72 \mathrm{MPa}$. Ispitivanja su rađena na epruvetama $(40 \times 40 \times 160 \mathrm{~mm})$, nakon starosti od 7 dana.

Glavno eksperimentalno istaživanje je rađeno za 6 različitih stabilizacijskih mešavina. Kao varijabilne komponente korišćeni su ukupna količina veziva i odnos učešća cementa i letećeg pepela u toj količini (tabela 2.). Granulometrijski sastav agregata je bio isti za svih 6 mešavina. 
Tabela 2. Sastavi mešavina cementnih stabilizacija koje su korišćene u eksperimentu

\begin{tabular}{|c|c|c|c|}
\hline Oznaka & $\begin{array}{c}\text { Dodatak } \\
\text { veziva } \\
{[\%]^{2}}\end{array}$ & $\begin{array}{c}\text { Učešće } \\
\text { cementa (C) } \\
\text { u vezivu [\%] }\end{array}$ & $\begin{array}{c}\text { Učešć letećeg } \\
\text { pepela (FA) u } \\
\text { vezivu [\%] }\end{array}$ \\
\hline M1 - 100C/OFA (4\%) & 4 & 100 & 0 \\
\hline M2 - 80C/20FA (4\%) & 4 & 80 & 20 \\
\hline M3 - 60C/40FA (4\%) & 4 & 60 & 40 \\
\hline M4 - 100C/OFA (6\%) & 6 & 100 & 0 \\
\hline M5 - 80C/20FA (6\%) & 6 & 80 & 20 \\
\hline M6 - 80C/20FA (6\%) & 6 & 60 & 40 \\
\hline
\end{tabular}

\subsection{Proctor-ov opit}

Prethodnim ispitivanjem, tj. Proctor-ovim opitom, određena je optimalna vlažnost (wopt) i maksimalna suva zapreminska masa $\left(\gamma_{s}\right)$ svih 6 stabilizacijskih mešavina. Ispitivanje je rađeno postupkom Standardnog Proctor-ovog opita (po standardu: EN 13286-2:2010), na cilindričinim kalupima prečnika $\mathrm{d}=10 \mathrm{~cm}$ i visine $\mathrm{h}=12 \mathrm{~cm}$. Energija zbijanja je iznosila $0,6 \mathrm{MJ} / \mathrm{m}^{3}$. Standardni Proctor-ov opit $\mathrm{i}$ navedene dimenzije kalupa su izabrane na osnovu nominalnog maksimalnog zrna agregata (koje je iznosilo $16 \mathrm{~mm}$ ). Navedene mešavavine su tretirane kao samodrenirajuće (self-draining mixtures), na osnovu dodatka D (Annex D) standarda EN 13286-2:2010. Maksimalne suve zapreminske mase $\left(\gamma_{s}\right)$ i optimalne vlažnosti (wopt), za različite stabilizacijske mešavine, date su u tabeli 3.

Tabela 3. Vrednosti maksimalnih suvih zapreminskih masa $\left(\mathrm{Y}_{\mathrm{s}}\right)$ za različite sastave mešavina

\begin{tabular}{|c|c|c||}
\hline Oznaka & $\begin{array}{c}\text { Optimalna } \\
\text { vlažnost, } \\
\text { Wopt }_{\text {op }} \text { [ }\end{array}$ & $\begin{array}{c}\text { Maksimalna suva } \\
\text { zapreminska masa, } \\
\gamma_{s}\left[\mathrm{~g} / \mathrm{cm}^{3}\right]\end{array}$ \\
\hline $\mathrm{M} 1-100 \mathrm{C} / 0 \mathrm{FA}(4 \%)$ & 6,8 & 2,15 \\
\hline $\mathrm{M} 2-80 \mathrm{C} / 20 \mathrm{FA}(4 \%)$ & 6,8 & 2,15 \\
\hline $\mathrm{M} 3-60 \mathrm{C} / 40 \mathrm{FA}(4 \%)$ & 6,8 & 2,15 \\
\hline $\mathrm{M} 4-100 \mathrm{C} / 0 \mathrm{FA}(6 \%)$ & 6,8 & 2,22 \\
\hline $\mathrm{M} 5-80 \mathrm{C} / 20 \mathrm{FA}(6 \%)$ & 6,8 & 2,22 \\
\hline $\mathrm{M} 6-80 \mathrm{C} / 20 \mathrm{FA}(6 \%)$ & 6,8 & 2,22 \\
\hline
\end{tabular}

Vrednosti optimalnih vlažnosti su za svih 6 stabilizacijskih mešavina, bez obzira na odnose učešća cementa i letećeg pepela u mešavinama, iznosile $6,8 \%$. Takođe, optimalne vlažnosti nisu bile zavisne od ukupne količine dodatka veziva (iste vrednosti wopt su bile za mešavine i sa 4 i sa $6 \%$ veziva), dok su vrednosti maksimalnih suvih zapreminskih masa $\left(\mathrm{y}_{\mathrm{s}}\right)$ bile zavisne od ukupnog dodatka veziva. Naime, vrednosti maksimalnih suvih zapreminskih masa za mešavine sa $4 \%$ ukupnog

2 Procentualni dodaci veziva su dati u odnosu na ukupnu masu agregata u mešavinama, pri čemu se pod pojmom vezivo smatraju cement i leteći pepeo dodatka veziva (M1, M2 i M3) su iznosile 2,15g/cm³, dok su vrednosti maksimalnih suvih zapreminskih masa za mešavine sa $6 \%$ ukupnog dodatka veziva (M4, M5 i M6) bile 2,22g/ $\mathrm{cm}^{3}$ (tabela 3.), pa se može zaključiti da se sa povećanjem ukupnog sadržaja veziva u mešavinama povećavaju i vrednosti maksimalnih suvih zapreminskih masa.

\subsection{Indirektna zatezna čvrstoća}

Povećanjem količine cementa u mešavini povećava se i pritisna čvrstoća stabilizacije, a samim tim i zatezne karakterisike stabilizacija, što je i cilj. Naime, kolovozne konstrukcije su sprecijalan primer građevinskih konstrukcija koje pored pritisnih čvrstoća moraju da imaju i znatne zatezne karakteristike, da bi kolovozna konstrukcija mogla da prihvati dinamičko opterećenje usled dejstva saobraćaja. Krutost kolovozne konstrukcije obrnuto je proporcionalna elastičnosti iste, pa je iz tog razloga potrebno ograničiti maksimalnu količinu cementa u stabilizacijskim mešavinama. Iz prethodno navedenog se zaključuje da su idealne cementne stabilizacije one koje imaju maksimalne zatezne karakteristke (indirektnu zateznu čvrstoću i dinamički modul elastičnosti) uz ispunjenje potrebne vrednosti pritisne čvrstoće, koja se po standardu SRPS U.E9.024:1980 ograničava na max 5,5MPa nakon 7 dana, odnosno na max 6,5MPa nakon 28 dana nege. Ispitivanje zatezne čvrstoće za noseće slojeve stabilizovane cementom nije propisano srpskim standardom. U svetu postoji više metoda za ispitivanje zateznih čvrstoća betonskih mešavina, a najpoznatije su:

- direktna zatezna čvrstoća,

- čvrstoća na savijanje,

- $\quad$ indirektne zatezna čvrstoća (ITS) - brazilski opit cepanja [3].

Izbor metode ispitivanja, između ostalog, zavisi i od dimenzija uzoraka, a uzorci koji se spravljaju za ispitivanje karakteristika cementnih stabilizacija odgovarajućih su dimenzija i za određivanje indirektne zatezne čvrstoće (slike 5. i 6.). Indirektna zatezna čvrstoća (ITS) je određena na osnovu standarda EN 13286-42 (slika 7.).

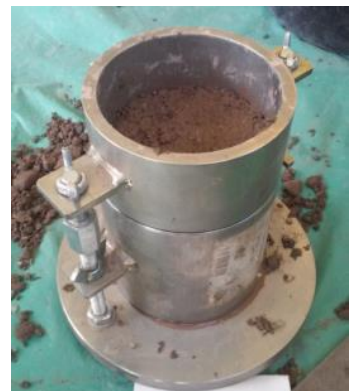

Slika 5. Uzorak spravljen u kalupu, za ispitivanje ITS-a

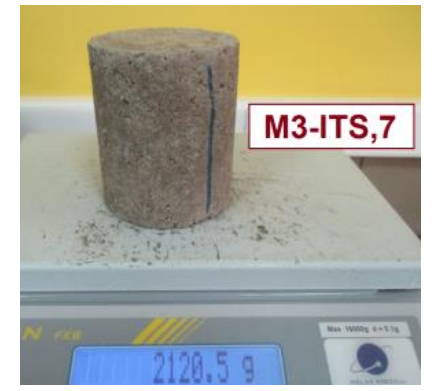

Slika 6. Izgled uzorka za ispitivanje ITS-a 


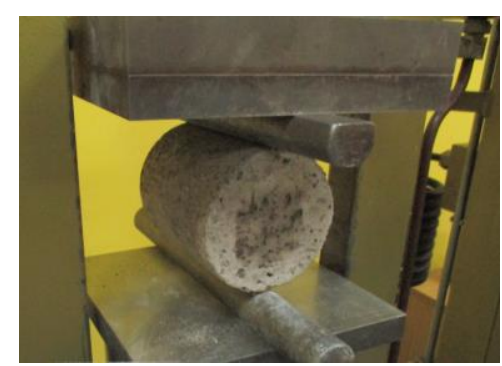

Slika 7. Laboratorijsko ispitivanje ITS-a (brazilski opit cepanja)

Pre postupka ispitivanja ITS-a, na svim stabilizacijkim mešavinama određena je zapreminska masa $(\mathrm{\gamma})$, gde je primećeno da je ona direktno proporcionalna količini ukupnog dodatka veziva i količini dodatka letećeg pepela $u$ mešavinama (dijagram 2.).

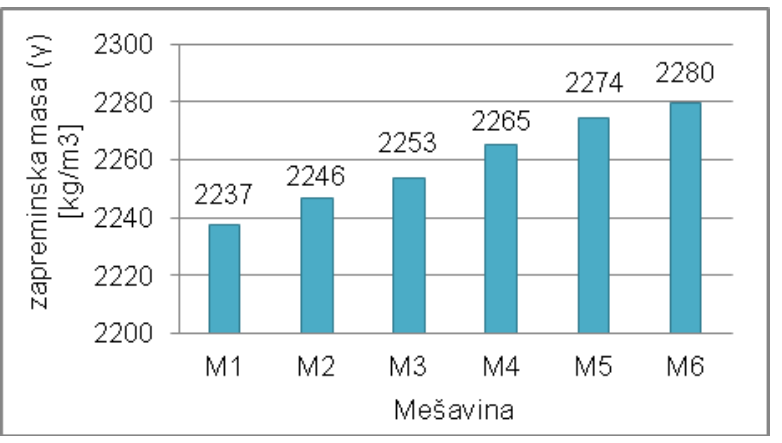

Dijagram 2. Vrednosti zapreminske mase $(\mathrm{\gamma})$ za različite stabilizacijske mešavine

Sa povećanjem sadržaja letećeg pepela u mešavinama, za istu ukupnu količinu veziva, zapreminske mase se povećavaju, što se može pripisati većoj zapremini koju zauzima leteći pepeo u odnosu na cement, za istu masenu jedinicu (zapreminska masa letećeg pepela je manja $u$ odnosu na cement).

Uzimajući u obzir činjenicu da u uzorcima stabilizacijskih mešavina (uvek ima zaostalog vazduha) veća količina letećeg pepela (u mešavinama M2 i M3, odnosno M5 i M6) će popuniti taj prazan prostor i povećati ukupnu zapreminsku masu uzoraka. Zapremiska masa se, očekivano, povećava i sa povećanjem ukupnog sadržaja veziva u mešavinama.

Laboratorijska ispitivanja indireknte zatezne čvrstoće su rađena za mešavine sa 4 i $6 \%$ veziva, nakon 7 i 28 dana nege cilindričnih uzoraka cementnih stabilizacija, za 6 različitih stabilizacijskih mešavina, a rezultati ispitivanja su dati na dijagramima 3., 4., 5. i 6.

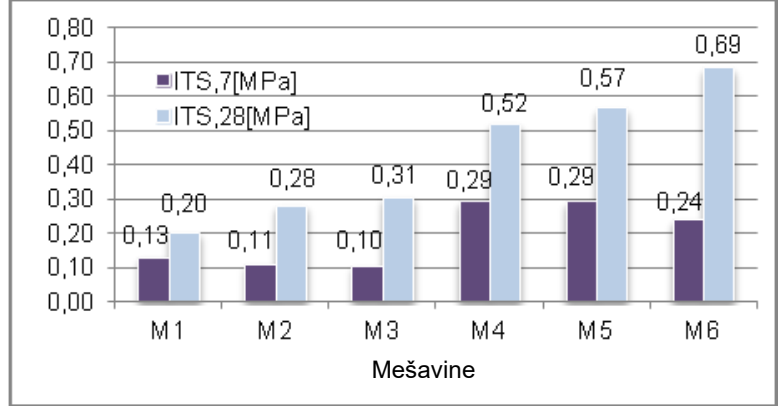

Dijagram 3. Uticaj perioda nege i sastava stabilizacijskih mešavina na vrednosti indirektnih zateznih čvrstoća (ITS)

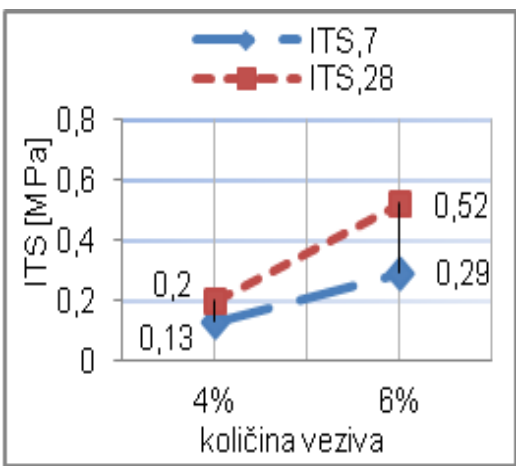

Dijagram 4. Uticaj količine veziva na vrednosti indirektnih zateznih čvrstoća (ITS), za čisto cementne stabilizacije (M1 i M4)

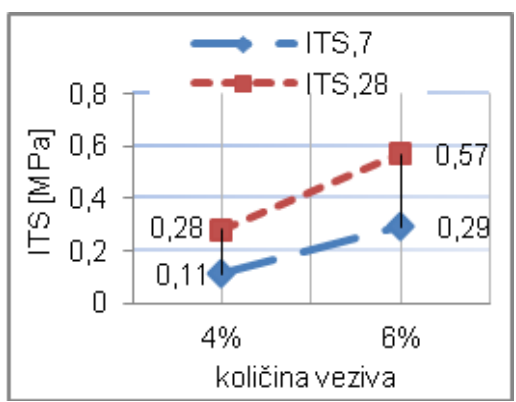

Dijagram 5. Uticaj količine veziva na vrednosti indirektnih zateznih čvrstoća (ITS), za mešavine sa $80 \%$ cementa i 20\% letećeg pepela (M2 i M5)

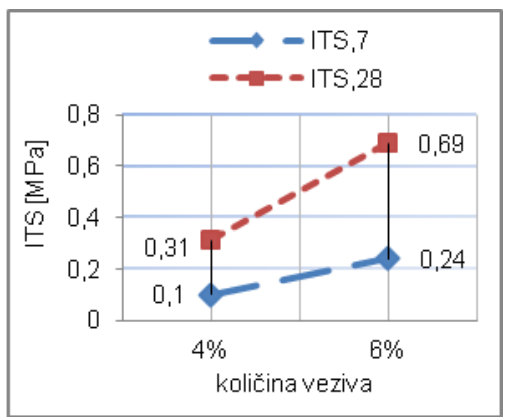

Dijagram 6. Uticaj količine veziva na vrednosti indirektnih zateznih čvrstoća (ITS) za mešavine sa $60 \%$ cementa i 40\% letećeg pepela (M3 i M6) 
Analizom dijagrama 3., 4., 5., i 6. može se zaključiti da se vrednosti indirektnih zateznih čvrstoća, za iste stabilizacijske mešavine, povećavaju sa periodom nege uzoraka. Najveći rast vrednosti ITS-a, u odnosu na period nege uzoraka, je za mešavinu M3 (210\%), a najmanji kod mešavine M1 (54\%). Takođe, sa povećanjem sadržaja letećeg pepela vrednosti ITS-a nakon 7 dana nege opadaju, dok se nakon 28 dana nege povećavaju, a to povećanje je direktno proporcionalno količini dodatka letećeg pepela za oba ukupna učešća veziva. Najveće vrednosti ITS-a su zabeležene kod mešavine M6, nakon 28 dana nege $(0,69 \mathrm{MPa})$, a najmanje kod mešavine $M 3$, nakon 7 dana nege $(0,10 \mathrm{MPa})$. Na dijagramima 4., 5. i 6. su prikazane vrednosti ITS-a u zavisnosti od količine ukupnog veziva i perioda nege uzoraka, za tri različita odnosa cementa i letećeg pepela u mešavinama. $\mathrm{Na}$ navedenim dijagramima je primetno povećanje vrednosti ITS-a sa povećanjem ukupnog sadržaja veziva, za sva tri slučaja odnosa cementa i letećeg pepela u stabilizacijskim mešavinama.

\section{ZAKLJUČAK}

Mogućnosti primene otpadnih industrijskih nusproizvoda, kao što je elektrofilterski leteći pepeo su velike, a stepeni njihovih iskorišćenosti veoma mali. Jedna od mogućih primena letećeg pepela iz termoelektrana je u gradnji puteva i to pri izradi cementnih stabilizacija kolovoznih konstrukcija. Eksperimentalnim istraživanjem dokazano je da leteći pepeo može uspešno da zameni deo količine cementa (20 i 40\%mas) u stabilizacijskim mešavinama, pri čemu može značajno da poveća vrednosti indrektne zatezne čvrstoće, koja je mera kvaliteta elastičnosti sloja cementne stabilizacije. Analizom rezultata prikazanog eksperimentalnog istraživanja ustanovljeno je da vrednosti indirektnih zateznih čvrstoća za mešavine sa dodatkom letećeg pepela (M2, M3, M5 i M6) nakon 28 dana nege rastu sa povećanjem sadržaja letećeg pepela (za razliku od ispitvanja nakon 7 dana nege), te se to može opravdati kasnijom pucolanskom reakcijom letećeg pepela.

Prednost primene letećeg pepela, pored njegove lake dostupnosti je $i$ ta što je to jedan od retkih otpadnih materijala koji se u betonskim kompozitima može koristiti u svom izvornom obliku, dakle bez neke prethodne obrade. Mogućnost njegove primene u navedenim kolovoznim konstrukcijama bi u svakom slučaju imala veliku opravdanost.

Kontrola količine ukupnog dodatka cementa u mešavini je veoma bitna stavka u projektovanju ovakvog tipa kolovoznih konstrukcija. Primena veće količine cementa od potrebne negativno utiče na kolovoznu konstrukciju, jer se u tom slučaju javljaju velike razlike u krutostima susednih slojeva.
Pravilnim odabirom količine dodatog cementa i granulacije agregata mogu se postići optimalni rezultati fizičkih, mehaničkih i hemijskih krakateristika za ovaj sloj kolovozne konstrukcije.

\section{Zahvalnost}

U radu je prikazan deo istraživanja koje je pomoglo Ministarstvo prosvete, nauke i tehnološkog razvoja Republike Srbije u okviru tehnološkog projekta TR 36017 pod nazivom: "Istraživanje mogućnosti primene otpadnih $\mathrm{i}$ recikliranih materijala $\mathrm{u}$ betonskim kompozitima, sa ocenom uticaja na životnu sredinu, u cilju promocije održivog građevinarstva u Srbiji".

\section{Literatura}

[1] Thomas, M. (2007). Optimizing the Use of Fly Ash in Concrete, Portland Cement Association, Illionois, US

[2] Cmiljanić, S., Vujanić, V. (2003). Problemi u primjeni elektrofitlerskog pepela i šljake u izgradnji puteva u Republici Srbiji, Savjetovanje o primjeni elektrofilterskog pepela i šljake u izgradnji putne infrastrukture, Tuzla

[3] Braunović, B. (1991). Kolovozne konstrukcije od stabilizovanog lokalnog materijala, Građevinska knjiga Beograd

[4] Brackett, C.E. (1979). Availability, Quantity and Present Utilization of Fly Ash, Proc.FACC, BMIC, Wahington D.C.

[5] Projekat: Uputstvo za korisnike nusproizvoda i upotrebu sekundarnih sirovina u izgradnji puteva, G2G09/SB/5/4 u okviru kratkog G2G programa, Agentschap NL TerrAdvies EVD Unit Internationale Publieke Samenwerking (2010).

[6] Tanasijević, Lj. (2011). Upotreba elektrofilterskog pepela i šljake proizvedenih iz termoenergetskih postrojenja, Privredna komora Srbije - internet prezentacija

[7] Dimter, S., Šperac, M. (2007). Stabilizacijske mješavine s letećim pepelom u nosivim slojevima kolničke konstrukcije, Zbornik radova, 1.bh kongres o cestama, Sarajevo, BiH

[8] http://carma.org/plant/detail/31240

[9] http://www.ecoba.com/ecobaccputil.html

[10] Mahvash, S., López-Querol, S., Bahadori-Jahromi, A. (2017). Effect of class $F$ fly ash on fine sand compaction through soil stabilization, Structural Engineering, Civil Engineering

[11] Дрндарски, Д. (2007). Рециклирање постојећих асфралтних коловоза, Рехабилитација и реконструкција путева, Златибор

[12] Dragaš, J., Marinković, S., Miličić, Lj., Marković, S., Tošić, N., Ignjatović, I. (2013). Geopolimeri na bazi alkalno aktiviranog elektrofilterskog pepela kao novo vezivo u betonu, IZGRADNJA 67 